\title{
The Subprime Mortgage Reforms: The Case of Us Market
}

\author{
Gurcharan Singh Pritam Singh \\ Edward Sek Khin Wong \\ Jee Yoong Folk \\ Faculty of Business and Accountancy, University of Malaya \\ Kuala Lumpur, Malaysia \\ E-mail: edwardwong@um.edu.my
}

\begin{abstract}
The downfall of the mortgage industry in US has seen fingers being pointed to the government sponsored entities (Fannie Mae and Freddie Mac), while the roots cause of the formation of these entities were never closely followed. Originally the creation of the GSE was to create liquidity in the mortgage industry as part of public policy in providing housing for the middle and lower income group. Over time, resulting from a weak regulated environment saw the GSE suffering and now this left questioning the effectiveness of the initial policy.
\end{abstract}




\section{Introduction}

In order to facilitate liquidity after the great depression, Fannie Mae was formed as a government agency in 1938. This was part of Franklin Delano Roosevelt's Deal, and was intended to stimulate the mortgage market in U.S. Since then Fannie Mae has played an integral part in the development of the mortgage market that aimed to benefit the public as a whole.

However, currently, U.S. is facing the subprime mortgage crisis which is threatening to depress the economy. The crisis began with the bursting of the United States housing bubble and high default rates on subprime mortgages. With the ongoing financial crisis characterized by evaporating liquidity in credit markets and banking systems, the role of such vehicle was questioned. What has gone wrong? Has its role in facilitating liquidity failed?

To clarify this issue, a comprehensive action research analysis of the changes that took place since its formation are discussed and presented as below (Wong, 2004,2005,2006,2007).

\section{Government Sponsored Enterprises}

Fannie Mae - whose full title is The Federal National Mortgage Association - and Freddie Mac - the Federal Home Mortgage Corporation - have been operating since 1068 as government sponsored enterprises (GSEs). Although they are privately owned (having shareholders) these two companies are financially supported by the Federal Government (Shin 2005). Fannie Mae operates as a national savings and loan entity, allowing local banks to charge low interest rates on mortgages for the benefit of the home buyer, which lead to the development of a secondary mortgage market. Fannie Mae enjoys high status and is able to borrow from foreign investors at low interest rates and offer home-buyers fixed-rate mortgages with low down- payments. Fannie Mae was privatised in 1968 and has been operating as a GSE, generating profits for stock-holders while enjoying the tax breaks and some implied government backing. In order to prevent any further monopolization of the market, a second GSE known as Freddie Mac was created in 1970.

As in early 2008, Fannie Mae and Freddie Mac controlled about 90 percent of the U.S.'s secondary mortgage market. The secondary mortgage market allows banks to sell mortgages, giving them new funds to offer more mortgages to new borrowers. Without it, banks would have to keep all mortgages on their books. The secondary market is how the repackaged subprime mortgages were securitized.

Over time both these GSEs experienced a period of unprecedented financial growth with a combined current asset exceeding 45 percent of that of the nation's largest bank. However both enterprises reported net losses in 2007. Fannie Mae reported a net loss of \$2.1 billion, whereas Freddie Mac reported a net loss of \$3.1 billion (McLean, 2005) (Table 1.1 below). The Enterprises' profitability was adversely affected by: substantially higher credit-related expenses and market valuation losses on some assets (stemming from expectations of higher future default costs), higher allowances for loan losses, and declines in the market prices of mortgage assets (Table 1.2 below).

As on the $7^{\text {th }}$ July, the shares of these two mortgage giants hit a 52 week low after the Lehman Brothers report raised concerns that its need for further capital injection. Loosing 


\section{Macrothink}

investors confidence saw it continued to drift down to a low of $\$ 0.99$ (end of October 2008) from its highest prime price of $\$ 65.54$ (Figure 1.1 below).

When the share price of Fannie and Freddie plunge, the US treasury felt that that they were obliged to approve extended credit lines. Besides that Federal Reserve also ensure that Fannie and Freddie could get financing at its discount window, a privilege previously only available to banks. Freddie Mac was able to raise \$3 billion in short-term finance but the deal did little to help the share price of the company. It dented further with the collapse of Indy-Mac, a mortgage lender.

Following this Moody's, a rating agency, downgraded both the financial strength and the preferred stock of Fannie and Freddie, making a capital-raising exercise looks even more difficult. Investors were puzzled as these giant twins were set up to provide liquidity to the housing market is now facing trouble and no one felt that the government would not let Fannie and Freddie fail; they have just been proved right.

Table 1.1. Annual Net Income: Fannie Mae and Freddie Mac

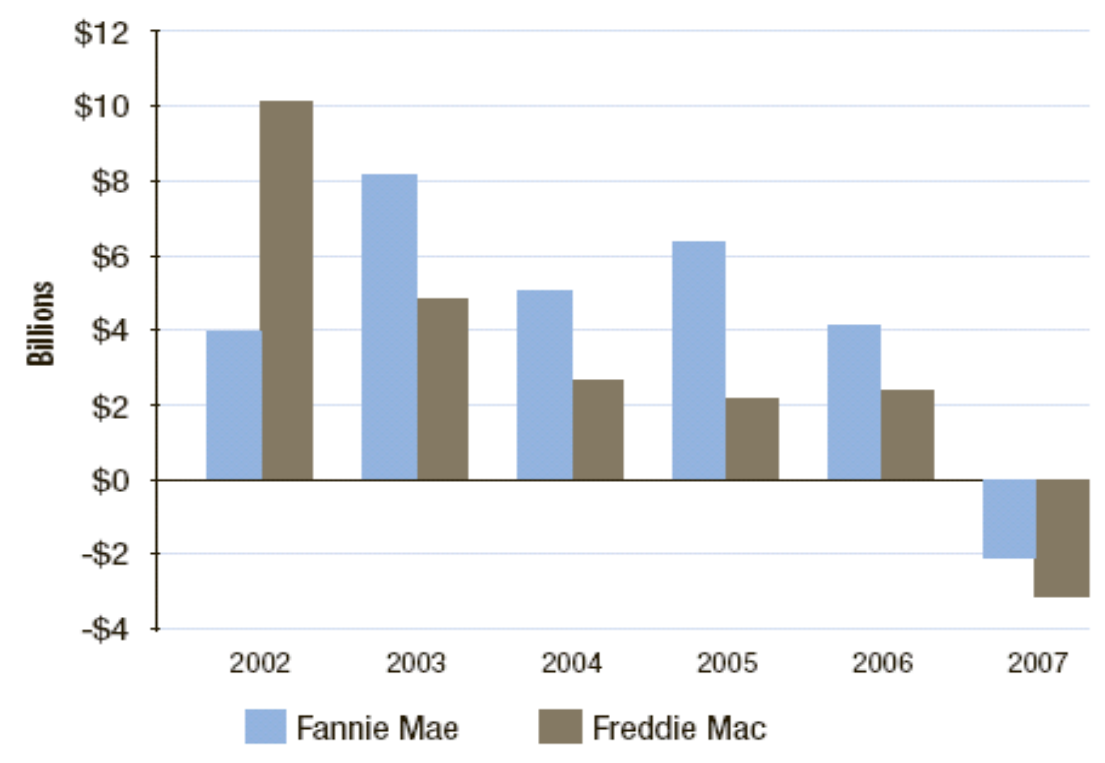

Source: Fannie Mae and Freddie Mac 


\section{Macrothink}

Table 1.2. House Price Index History for USA (Seasonally-Adjusted Price Change Measured in Purchase-Only Index)

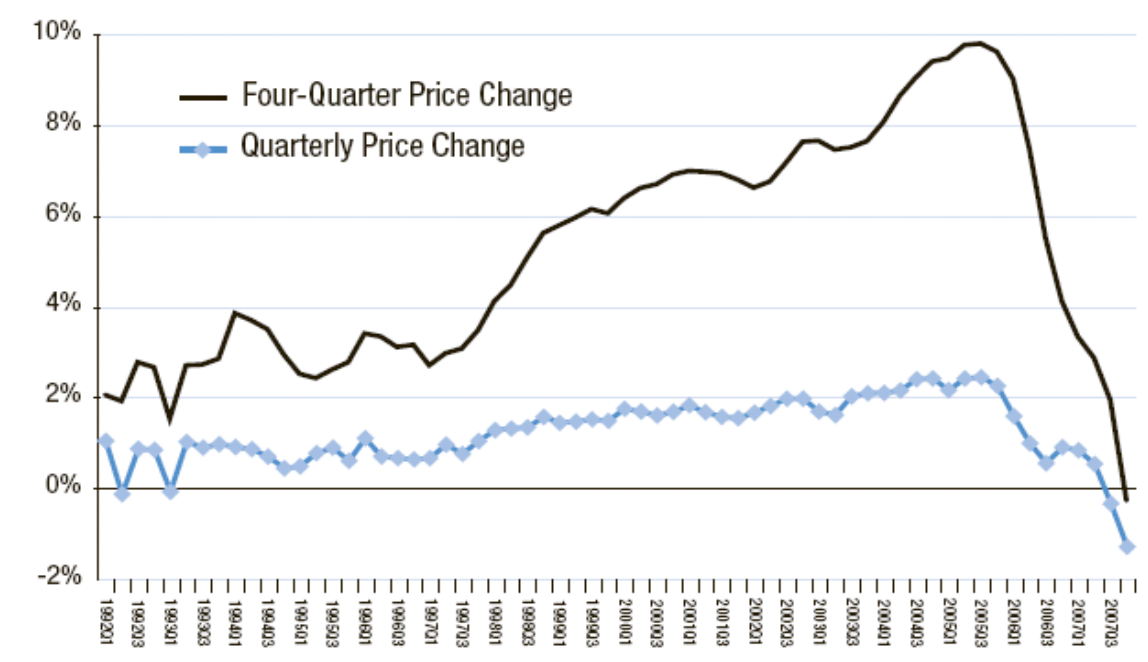

Source: Office of Federal Housing Enterprise Oversight

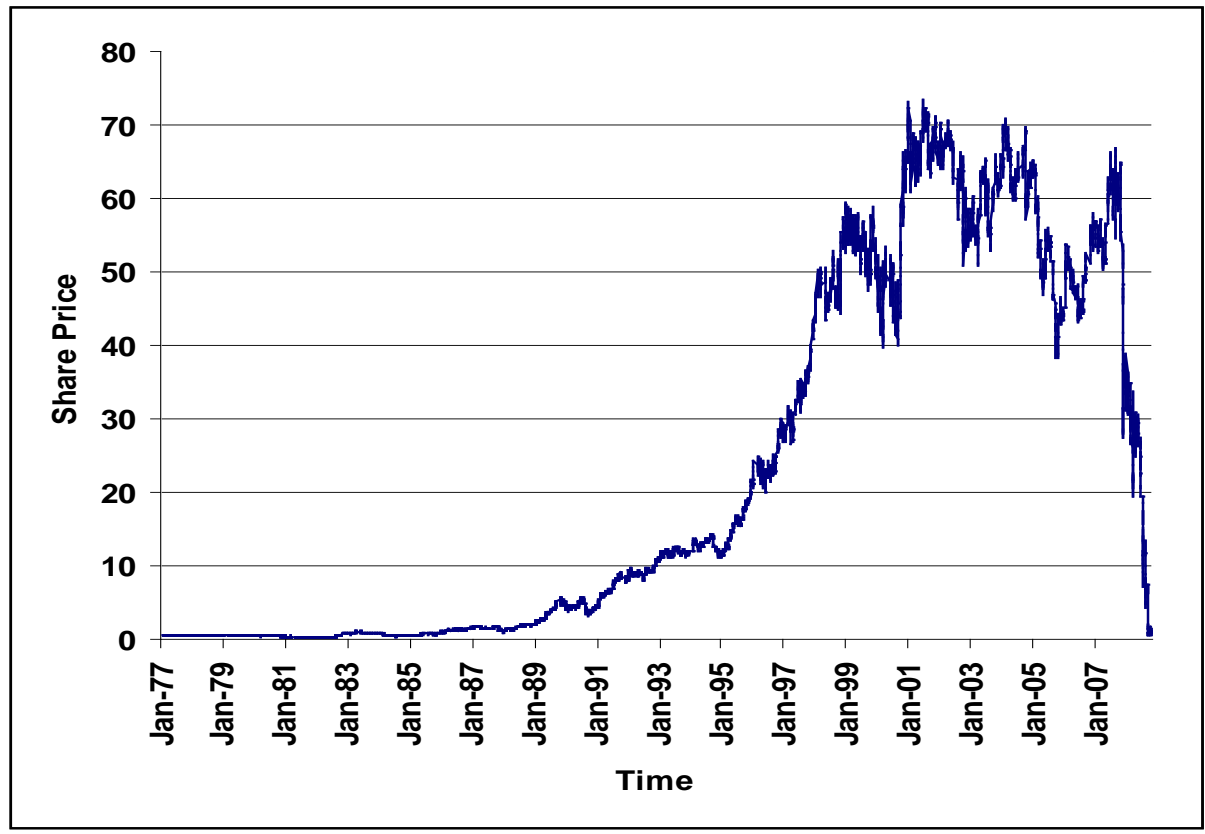

Figure 1.1. Adjusted Closing Price of Fannie Mae \& Freddie Mac

Source: Yahoo Finance.com

So, was the plunge in the stock price of Fannie Mae and Freddie Mac a result of the descending demand in the housing market? Or has the mortgage market expanded excessively that result in the stagnation of home prices? Or was this an indicator of a failed government public policy? 


\section{Subprime Mortgage Market Crisis}

How did all this happen? Was it due to the wild greed and market failure? Or was it because the basic role of the secondary mortgage industry was to provide housing for the needy minorities and low-income Americans failed?

Partially this story of providing housing for the needy could be true. Where, easy credit policy stimulated housing demand and caused a surplus of inventory of homes which placed significant downward pressure on housing prices. Refinancing became difficult and this led to a sudden increase in defaults that reduced the value of mortgage-backed securities. However the missing element is the role of politicians and policy makers in creating artificially high housing prices (refer to Table 1.2), and artificially reducing the danger of extremely risky assets which should be considered seriously.

Those things started to happen as begin as early as in 1992, where the Congress pressured Fannie Mae and Freddie Mac to increase their purchases of subprime mortgages going to low and moderate income borrowers. In 1995, Fannie Mae and Freddie Mac began receiving affordable housing credit for purchasing mortgage backed securities which included loans to low income borrowers. The U.S. Department of Housing and Urban Development (HUD) instructed Fannie and Freddie to have a 42 percent target of their mortgage financing assigned to borrowers with income below the median in 1996. The target was later increased to 50 percent in 2000 and then to 52 percent in 2005 (Bloomberg, 2008).

This directive from HUD clearly indicated that 12 percent of all purchased mortgage should be under the term of "special affordable loans". Such loans were targeted to borrowers with an income less than $60 \%$ of their area's median income. This figure was pushed further to 20 percent, 28 percent and then to 29 percent in year 2000, 2005 and 2008 respectively. The beauty of the policy was Fannie Mae and Freddie Mac was able to achieve these targets funding billions of dollars worth of loans and many of them to sub-prime and low adjustable-rate loans made to borrowers with special privilege buyers with less than $10 \%$ down payments.

These government's mortgage policies fuelled the trend towards issuing risky loans i.e. to low income and high risk borrowers. As September 30, 1999 New York Times article reported,

"... the Fannie Mae Corporation is easing the credit requirements on loans... The action... will encourage those banks to extend home mortgages to individuals whose credit is generally not good enough... Fannie Mae... has been under increasing pressure from the Clinton Administration to expand mortgage loans among low and moderate income people... borrowers whose incomes, credit ratings and savings are not good enough... Fannie Mae is taking on significantly more risk... the government-subsidized corporation may run into trouble... prompting a government rescue... the move is intended in part to increase the number of... home owners who tend to have worse credit ratings..." (The New York Times, 1999) 
Later on the September 10th, 2003, U.S. Congressman Ron Paul indicated in his speech to Congress that the current government policies encouraging lending to people who couldn't afford to pay the money back could be risky, and he predicted that this would lead to a serious bailout in the long term, and he did introduced a bill to abolish these policies.

Next, there is also the issue of being greed. Fannie Mae and Freddie Mac also purchased a huge amount of sub-prime securities for their own portfolios to make money and to help satisfy HUD's “affordable housing” goals. This is joint profit making and achieving social objectives i.e. to serve both their investors and the political class (Frame and White, 2006). This was done with Fannie and Freddie designed to supplement home ownership among the poor people and simultaneously allowed the Congress and the White House to subsidize low-income housing outside their budget (Hockett et al., 2005), i.e. being a political free lunch.

In addition to the above, The Community Reinvestment Act (CRA) passed in 1997 pressuring banks to serve poor borrowers and poor regions of the country. Politicians could easily push for increases in home ownership and urban development without having to commit budgetary dollars. And between 2000 and 2002 Fannie Mae securitized \$394 billion in CRA loans with $\$ 20$ billion going to securitized mortgages to help serve such borrowers (Hawthrone, 2008).

With the CRA pushing-up the demand for relatively low-priced property, made matters worse when Taxpayer Relief Act (1997) increased the demand for higher valued property by having a higher tax relief. This was done by extending the availability and size of the capital-gains exclusion from $\$ 125,000$ to $\$ 500,000$. This relief also includes rental property. This effect of the CRA was to fuel an increase demand for housing (Andrew et al., 2008).

In addition to that, The Federal Reserve, the Central Bank of the United States, contributed to this mess. Since 2001, Alan Greenspan the Federal Reserve chairman from 1987 to 2006, advocated lowering interest rates and continued a strong money supply growth policy. Early 2003 saw the federal-funds rate being as low as 1.25 percent and this indirectly pushed the rates on adjustable loans to historic lows, helping stimulate the housing demand. The public were prompted to buy properties and even speculate in them. Greenspan was well known for lowering rates aggressively to counter any crisis and by doing that the market forces ran free and were never allowed to adequately correct the imbalances.

This later led to the credit explosion where there was excessive liquidity in the system. Back in 2004, Greenspan also opposed tougher regulation of financial derivates e.g. mortgage-backed securities. In 2003, he directed the Senate Banking Committee "What we have found over the years in the marketplace is that, derivates have an extraordinary useful vehicle to transfer risk from those who shouldn't be taking it to those who are willing to and are capable of doing so".

Now with tax relief act policy combined with low interest rate and easy access to credit saw an exponential increase in demand for houses and homeownership, including the low-income homeowners (Table 1.3). There was also an increase in the speculative activities in the 
housing market. This helped fuel the rise of home prices in the US market between 1997 and 2005, the average price of a house in the U.S. doubled.

Table 1.3. Total Home Sales

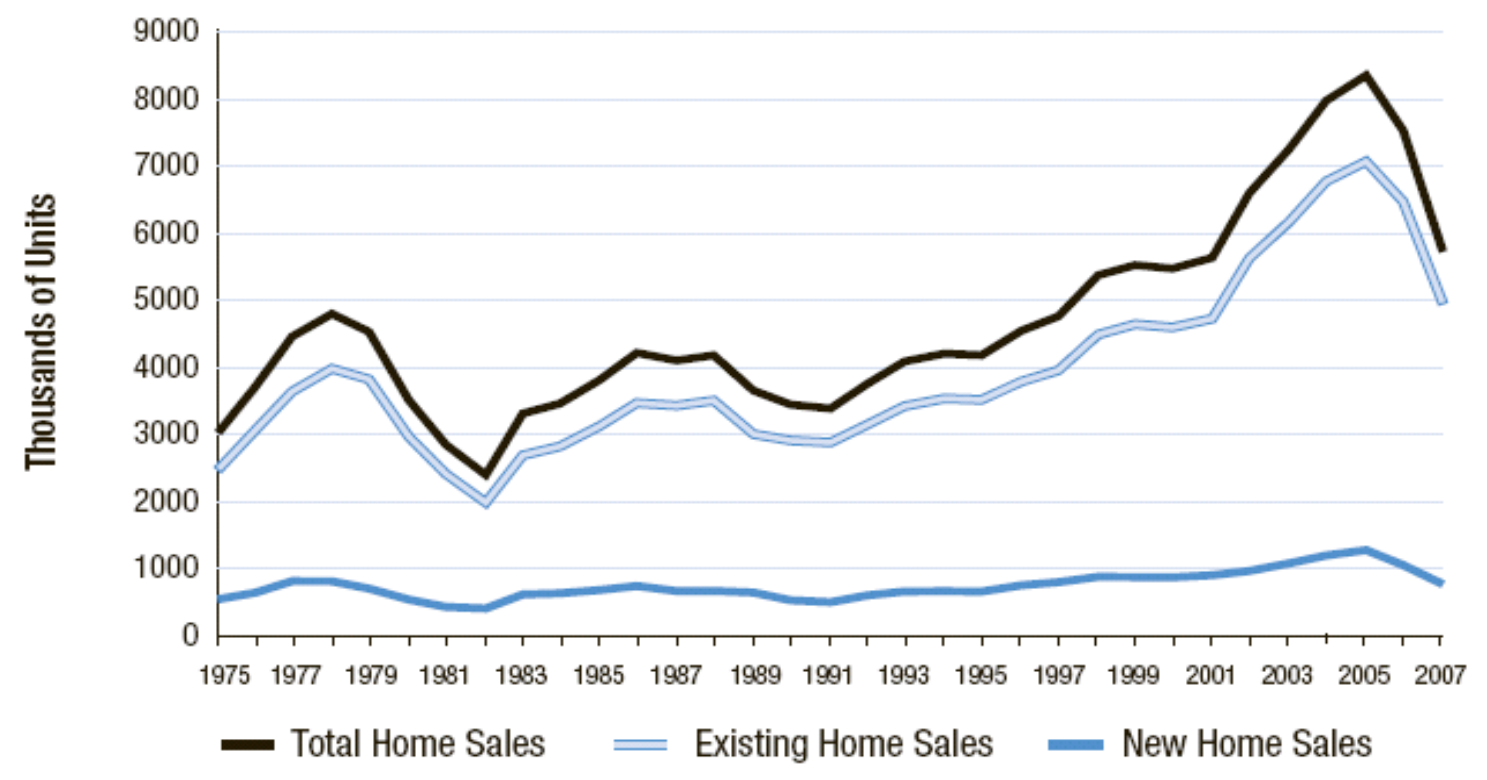

Source: National Association of Realtors and Bureau of the Census

A spiral effect from all the factors above immediately saw the National Association of Realtors composite index value in 1997 increased rapidly, where families earning medium income have 126.6 percent of their income needed to purchase any medium-priced existing houses. This figure is 1 percent above the second quarter of 1997 and 2 percent above the third quarter of 1996. This increase is the result of a 25-basis-point decrease in the interest rate and a 1-percent rise in median family income more than offsetting a 2-percent increase in the median home price during the last quarter (Table 1.4 below). This clearly indicates the rapid change house affordability as early as in 1997.

Table 1.4. Housing Affordability 1997

\begin{tabular}{|l|c|c|c|c|c|}
\hline & $4 \mathrm{t}$ Quarter & $3^{\text {rd }}$ Quarter & $\begin{array}{c}\text { Same Quarter } \\
1996\end{array}$ & $\begin{array}{c}\text { \% Change From } \\
\text { Previous }\end{array}$ & $\begin{array}{c}\text { \% Change } \\
\text { From 1996 }\end{array}$ \\
\hline $\begin{array}{l}\text { Composite } \\
\text { Index }\end{array}$ & 126.6 & 125.2 & 123.5 & +1 & +2 \\
\hline $\begin{array}{l}\text { Fixed Rate } \\
\text { Index }\end{array}$ & 124.0 & 121.6 & 118.9 & +2 & +4 \\
\hline $\begin{array}{l}\text { Adjustable } \\
\text { Rate Index }\end{array}$ & 137.7 & 136.4 & 133.5 & +1 & +3 \\
\hline
\end{tabular}

Source: US National Association of Realtors 
In summary, the Fed's measures had let the nation's real estate market continue to boom with cheap credit because of low interest rates, but they failed to snuff out the price increase with higher rates. Finally the housing boom came to a halt in 2005 and last year witnessed the burst of the housing bubble. Much of the rise in housing prices was the result of public policies that increased the demand for housing (Council of Economic Advisers, 2005). Without the surge in housing prices, the sub-prime market would have never taken off.

From the facts above it can be concluded that Fannie and Freddie played a significant role in the explosion of sub-prime mortgages and sub-prime mortgage-backed securities. Without Fannie and Freddie's implicit guarantee of government support, the mortgage-backed securities market and the sub-prime wouldn't have magnified at the undesirable rate (Hilzenrath and Day, 2006). However it could also be argued that Fannie and Freddie were basically carrying out the instructed public policy.

\section{Conclusion}

Who or what are the real cause of such a calamity? Although Fannie and Freddie played a significant role, they cannot be held totally responsible. A more sensible conclusion could be drawn towards the policies that began to spread in 1999 and "political class greed" to push home-ownership to a historical high of $72 \%$ in 2007 as compared to a low of $64 \%$ in 1994 . Both the current and previous U.S. president trumpeted the effectiveness of its public policy without considering its consequences. Putting the entire financial system and economy at risk, because significant hidden costs were channelled into the housing market instead of more productive assets.

\section{Reference}

Andrew C., Thomas C., Noel C., and Mitchell E., (2008). We can keep People in their Homes. Wall Street Journal, [Online] Available: http://online.wsj.com/article/SB122523972217878309.html, 29 ${ }^{\text {th }}$ October 2008.

Bloomberg News. (2008). Mortgage Finance Giant Freddie Mac Gushes Red Ink, August 8.

Council of Economic Advisers. (2005). Economic Report of the President, pp. 366-367, and U.S. Bureau of the Census, "Housing Vacancies and Homeownership (CPS/HVS), Annual Statistics: 2004,” revised February 17, Table 12.

Fama W. S., and White L. J., (2006). Fussing and Fuming over Fannie and Freddie: How Much Smoke, How Much Fire. Journal of Economic Perspectives, Vol. 19, No. 2, p 172.

Hilzenrath D. S., and Day K. (2006). After Scandals, Someone Must Pay. The Washington Post, January 20, p. B1.

Hawthrone, D. B. (2008). Defining Government's Role in the Current Financial Mess, [Online] Available: http://www.anchorrising.com/barnacles/006423.html, 5 ${ }^{\text {th }}$ October 2008.

Hockett D., Patrick M.E., Danilo P., Diane S., and Mark T. (2005). The Crisis in America’s Housing: Confronting Myths and Promoting a Balanced Housing Policy. Center for Community Change, Center for Economic and Policy Research, Children's Defense Fund, 


\section{Macrothink}

Research in Applied Economics

ISSN 1948-5433

2009, Vol. 1, No. 1: E11

Community Learning Project, and National Low Income Housing Coalition, January, pp. 7 and 13.

Mclean B. (2005). The fall of Fannie Mae. Fortune, January 10.

Shin A. (2005). House Panel Approves New Fannie Regulator. The Washington Post, May 26, p. E1.

Wong, E.S. (2004). Action Research: The Living Thesis, Centre of Reflective Practitioner Resources publication, Perth, Australia.

Wong, E.S. (2004). Action Research Philosophy: The Fountain of Living Research, Centre of Reflective Practitioner Resources publication, Perth, Australia.

Wong, E.S. (2005). Action Research: The Post-Modern Concept, Centre of Reflective Practitioner Resources publication, Perth, Australia.

Wong, E.S. (2006). Action Research: A Post- Structural and Post-modern Dissertation, Centre of Reflective Practitioner Resources publication, Perth, Australia.

Wong, E.S. (2007). Action Research in Social Science, Centre of Reflective Practitioner Resources publication, Perth, Australia. 